\title{
Lessons Learned in Management, Marketing, Sales, and Finance Incentive Practices a Decade after the Subprime Mortgage Crisis
}

\author{
Jason Earl Thomas ${ }^{1}$ \\ ${ }^{1}$ School of Business and Communication, Concordia University Texas and Coangelo College of Business, Grand \\ Canyon University, Phoenix, USA \\ Correspondence: Jason E. Thomas, School of Business Communication, Concordia University Texas and \\ Coangelo College of Business, Grand Canyon University, Phoenix, USA. Tel: 1-512-655-3038. E-mail: \\ jason.thomas@concordia.edu
}

Received: January 13, 2017

Accepted: February 4, 2017 Online Published: February 22, 2017

doi:10.5539/ijbm.v12n3p19

URL: https://doi.org/10.5539/ijbm.v12n3p19

\begin{abstract}
The subprime mortgage crisis was the most devastating financial crisis since the Great Depression. The steady rise of housing purchases and seemingly limitless increase in home values drew many investors to the United States real estate market. The business growth in this sector was so compelling that financial firms created new secondary markets that were perceived as diversifying risk, which in turn prompted lenders to create innovative funding vehicles and loose and fast loan qualification processes. The federal government was ill prepared to deal with this shift in the financial world to market-based demand, and the results were disastrous. Lenders embraced predatory lending practices, borrowers with bad credit overextended themselves beyond their means, and foreclosures occurred at startling rates as home values plummeted, resulting in a world-wide economic depression. Ten years later, we reflect on the events that led up to and caused the subprime mortgage crisis for lessons learned to improve management, marketing, and finance incentive practices.
\end{abstract}

Keywords: management incentives, marketing incentives, finance incentives, subprime mortgage crisis

\section{Introduction}

In a world where technology has eliminated barriers in global commerce and consumers and businesses are connected from the far reaches of the globe with smart phone applications, George Santaynana's aphorism regarding the consequences of ignoring the past takes on a hair-raising, prophetic quality. It's been a decade since the financial crisis wreaked havoc on the United States real estate market and the global economy. Accordingly, a dispassionate analysis of the crisis in the cold light of time may yield lessons that can be used to refine practices in management, marketing, and finance incentives to ensure prevention of similar events.

The subprime mortgage crisis had major negative effects for banks and the world financial market and developed into the most devastating financial crisis in the United States since the Great Depression (Blinder, 2010; Bernanake, 2009). The real estate market was devastated by sharp increases in mortgage foreclosures and delinquencies in North America, especially in the United States (Bernanke, 2007a). The crisis, which began at end of the 20th century, came to a head in 2007 and has highlighted systematic weakness in the regulation and deregulation of United States and world financial systems, as well as the potentially destructive impact of incentives used in the financial industry (Bernanke, 2009). Many believe the subprime mortgage crisis to be a root cause of the 2008 economic downturn that negatively affected the entire world economy.

An estimated four fifths of mortgages given in the United States to subprime applicants were mortgages with adjustable rates (Dodd, 2007). Adjustable-rate mortgages (ARMs) are mortgage loans where the interest rate on the note is adjusted periodically based on a variety of indices, such as the one-year Constant-Maturity Treasury (CMT) securities, the London Interbank Offered Rate (LIBOR), and the Cost of Funds Index (COFI) (Wiedemer, 2000). This structure assures preservation of the lender's margin, as the cost of funding is often tied to the index. As a result, the borrower's payment amount changes over time as interest rates change, transferring a portion of the interest rate risk to the consumer responsible for the loan. As interest rates rise, the loan becomes less favorable to the borrower.

In the United States, the housing market peaked in 2006 and then began a sharp decline. Consequently, 
refinancing mortgages became challenging for borrowers. Monthly payments for ARMs increased, and delinquencies in mortgages started occurring at alarming rates. This created a chain reaction of negative financial events. Securities supported with subprime mortgage loans, held by many financial firms, immediately started to lose significant value. The business model of originating inferior-quality loans for the purpose of generating quick profits from loan origination fees proved extremely risky due to its dependence on a stable secondary mortgage market, which relies heavily on the continued appreciation of home value (Jaffee, et al. 2009; Purnanandam, 2011). The unforeseen drastic change in market value caused a sharp decrease in the capital available to banks and government-initiated projects, which propagated across the world and severely limited interbank lending.

\section{The Evolution of the Subprime Mortgage Crisis}

Two items facilitated the environment of easily available credit that fueled the lending interactions prominent during the subprime mortgage crisis (Bernanke, 2009):

1. Vast amounts of foreign money supplied to the United States from rapidly growing foreign economies in Asia and the Middle East

2. Interest rates in the United States economy from 2002 to 2004

The new wave of easily available credit fueled both consumer credit and housing bubbles. Several types of loans such as automobile, credit, and mortgage were attainable with limited screening and weak credit history, which stimulated an increase in consumer borrowing and raised average consumer debt levels to all-time highs (Bernanke, 2009).

The subsequent credit and housing booms significantly increased the number of mortgage-backed securities (MBSs). This new phenomenon allowed investors, both private and institutional, from all over the globe to buy into the United States home market. As home prices began their sharp decline, financial institutions all over the world with large investments in subprime MBSs began to report major losses. The crisis expanded to other parts of the economy, and defaults on other loan types began to increase. According to the International Money Fund, total losses are estimated at more than $\$ 1$ trillion per year (Bernanke, 2009).

As the credit and housing bubbles festered, several other factors contributed to the fragile state of the financial system. No one recognized the growing importance of the role of nonbank financial institutions such as hedge funds, pension funds, and investment banks. The economy shifted to a more market-based finance system, and these nonbank financial institutions became increasingly important, though they were not subject to the same scrutiny and regulation as traditional depository banks (Geithner, 2008; Hoenig, 2008).

Financial institutions of all types took on increasingly large debt burdens while simultaneously passing out subprime loans without sufficient reserves to absorb significant loan defaults on MBS-based losses (Greenspan, 2009). The lending capabilities of these financial institutions were reduced, greatly affecting economic momentum. As the economy began to slow down, concerns grew over the stability of financial institutions and central banks took action to stimulate lending and confidence in the market for commercial paper, which is a core component of how businesses are funded. Later, the federal government provided bailouts for key financial institutions assuming large amounts of debt.

The strongest contributing factor to the crisis was the burst of the United States housing bubble in 2005 and 2006. The tremendous number of defaults on ARMs and subprime mortgages followed immediately after the burst at an alarmingly increasing rate over time. Borrowers were enticed to take on challenging loans by incentives like the long-term trend of increasing home values, easy loan initiation terms, and the belief in refinancing later with ease. As housing prices began to drop in 2006 and 2007, refinancing became difficult. Foreclosures and defaults increased dramatically as initial ARM loan terms expired. Housing prices did not increase as expected, and ARMs converted to higher interest rates. Falling home values created situations where many borrowers were upside down on their mortgages, meaning the value of the home is significantly less than the amount owed on the mortgage. This provided a strong incentive for borrowers to default on loans.

This phenomenon negatively affected both consumers and lending institutions. The danger created by the fall of the United States home market and the crisis in financial markets were the main drivers for central banks all over the globe to reduce interest rates and for the creation of economic stimulus packages. Effects from the crisis were significant for the global stock market. Corporations suffered trillions of dollars in losses, and stock prices plummeted around the world. 


\section{Methodology of Literature Review}

This literature review was conducted in accordance with the recommendaed principles of a systematic literature review which include (Jesson, Matheson, \& Lacey, 2011):

1. Field mapping by means of scoping review

2. Searching comprehensively

3. Extraction of data

4. Synthesis of data

5. Writing up findings and discussion.

A research plan was developed utilizing research questions, keywords, and sets of inclusion and exclusion criteria. The goal of the project was to examine the subprime mortgage crisis for lessons learned to improve practices of management, marketing, sales, and finance incentives. The research questions were:

1. How did the subprime mortgage crisis come to be?

2. What were the effects of the subprime mortgage crisis on the mortgage industry?

3. What factors contributed to the evolution of the subprime mortgage crisis?

Key word searches were conducted to guide searches for relevant peer-reviewed literature and historical reports (both from the government and new sources). Sources for research included online libraries and databases such as Proquest and GoogleScholar as well as general internet searches. After all releveant data were gathered and analyzed the findings were summarized.

\section{Presentation of Findings}

\subsection{Effects on the Mortgage Industry}

During this time, borrowers receiving subprime mortgages typically had poor credit scores, bad credit histories, and low income, resulting in an inability to make high-dollar mortgage payments. Subprime loans are riskier than standard loans and have a higher probability of ending in default than standard loans (FDIC, 2001). If the borrower does not make timely and sufficient payments on the loan according to the loan agreement, the loan holder may foreclose on the loan.

The total value of subprime mortgages in the United States in March 2007 has been estimated at $\$ 1.3$ trillion (Associated Press, 2007). Of those mortgages, \$7.5 million were first-lien-type subprime mortgages (Bernanke, 2007b). According to Harvard University's State of the Nation's Housing 2008, the percentage share of subprime mortgages grew from $10 \%$ between 2001 and 2003 to 18 to $21 \%$ between 2004 and 2006 (Alexander \& et al., 2008). The Mortgage Bankers Association (2007) states that in the third quarter of 2007, subprime ARMs comprised only $6.8 \%$ of mortgages in the United States but simultaneously made up $43 \%$ of the foreclosures that were initiated in the quarter. By October 2007, an estimated 16\% of subprime ARMs were greater than 90 days delinquent or were undergoing foreclosure proceedings (Bernanke, 2007b). This was three times the rate in 2005 and continued climb to $21 \%$ in January 2008 and still further to $25 \%$ by May 2008 . Greater than $14 \%$ of all mortgages in the United States were undergoing the foreclosure process or were delinquent by September 2009 (Mortgage Bankers Association, 2009).

\subsection{Factor Contributing to the Subprime Mortgage Crisis}

Issues with both the credit and housing markets were incubated over several years. Several factors contributed to the subprime mortgage crisis. One main cause was borrower inability to make mortgage payments. Borrowers struggled to make payments for several reasons (Steverman \& Bogoslaw, 2008):

\section{Lack of understanding of financial risk}

2. Purchasing larger, more expensive homes than they could realistically afford

3. Hope that interest rates would continue to decline

4. ARM resets and subsequent increased monthly payment amounts

5. High debt levels

The state of government regulation and financial business practices also contributed to the subprime mortgage crisis. Institutional factors that contributed to the crisis include the following:

1. Lack of regulation 
2. Predatory lending practices

3. High levels of commercial debt with limited reserves

4. Lax monetary polices

5. World trade imbalances

According to Dodd (2007), three major driving factors coalescing to fuel the crisis were the predatory practices of mortgage brokers regarding ARMs, large numbers of banks that newly embraced the mortgage bond market, and large quantities of money entering the market from the private sector. Many suggest that improper insulation from risk due to lack of awareness or education was a major factor facilitating the rash consumer behavior that drove the borrowing - the catalyst for the subprime mortgage crisis.

\subsection{Housing and Construction Boom}

Declining interest rates and infusion of funds from foreign investors made credit easy to obtain in the period prior to the credit crisis. President G. W. Bush (2008) stated that this readily available credit fueled a boom in the housing market and fostered debt-financed consumption. Subprime lending led to all-time highs in home ownership rates, which increased home purchase prices.

As home prices grew, people were saving less but spending more. Increased home values due to increased demand allowed homeowners to have access to higher lines of home equity credit. With access to more "cash" from these lines of credit and inflated home values, consumers cashed in and doubled their use of these home equity funds (Reuters, 2007). Eventually this credit and home value growth fueled a construction boom for the homebuilding industry. The combination of readily available credit and strong belief in the fact that home prices would continue to appreciate caused many people to buy homes, even those who should not have - many borrowers obtained subprime ARMs hoping that rates would continue to decrease. Many lenders found refinancing difficult to obtain as interest rates rose and their poor credit offered them even more unfavorable rates than those on the ARMs they could not afford to service. Over time, this resulted in a surplus of new homes, as housing prices could not continue to appreciate artificially and demand died off before new construction was completed. Borrowers found themselves in a financial vise, unable to make payments on the reset ARMs and unable to refinance to stem the bleeding incurred by rising rates.

As foreclosures started occurring, more homes were put on the market and home supply increased, driving prices and home values down. This led to evaporation of home equity and made some borrowers upside down (owing more than their property was worth). The reduction in monthly home payments reduced the strength and health of MBSs, damaging banks' financial health and creating a spiraling cycle of decline.

\subsection{Real Estate Investing}

Another factor contributing to the subprime mortgage crisis was that some consumers saw the easy credit and increasing home values as an opportunity to invest for profit or to buy vacation homes. For the same reasons that new homeowners entered the market and overextended themselves, other consumers overextended themselves by entering the investment market where they wouldn't have otherwise. According to Leslie (2007), second-home sales grew $4.7 \%$ in 2005 to an all-time record of 1.07 million units sold. These dropped just as fast in 2006 and fell some $28.9 \%$. The combination of investor focus on need for income from their properties and the easy ability to abandon vacation homes and investment properties caused this market to fall much more rapidly that the primary home market.

This investor speculation effect continued to fuel and accelerate the increased supply of homes on the market. Trends developed in real estate investment and even in the popular media, such as real estate flipping. As the supply of homes on the market continued to increase, prices continued to drop. The decrease in home values continued to weaken banks and homeowner equity and increased the risk of default. The cycle continued to churn.

\subsection{Loan Processing}

The years prior to the subprime mortgage crisis saw dramatic changes in the way lenders operated. The amount of subprime loans offered to high-risk applicants dramatically increased. Subprime loans grew from $5 \%$ of loan originations in 1994 to 20\% in 2006 (Arnold, 2007). This change was caused by reduced application standards, where lenders offered loans to borrowers with more risky credit profiles. Lenders also required significantly lower down payments for primary residences.

One example of how loan qualification guidelines changed during this period was the use of stated-income, verified-asset (SIVA) loans. SIVA loans do not require borrowers to demonstrate income. Borrowers simply 
needed to declare that they have income or employment and have money in the bank. In the years before the crisis, SIVA loans were followed by no-income, verified-asset (NIVA) loans. NIVAs have even looser loan qualification criteria. Borrowers don't have to declare that they have income; they only need to have money in a bank account. Finally, even this loosely restricted loan vehicle was made less constrictive, and no-income, no-asset (NINA) loans were established. For this new loan, a statement of employment is not required, and borrowers are not required to have money in the bank. An acceptable credit score is the only thing required for a NINA loan.

As lenders saw the figurative "blood in the water" for the growing housing market, opening access to loan applications was not enough to stimulate borrowing to meet the market potential perceived by bankers. Lenders attacked another aspect of loan purchasing, monthly payments (Arnold, 2007). A new form of ARM came into practice, the interest-only ARM. In this modified ARM loan, the borrower pays a reduced monthly payment during the initial period where only interest is paid on the loan (not principle). Another loan vehicle that targeted even more inexpensive payment options was the payment option loan, which allows the borrower to pay a flexible amount each month. Interest unpaid in the monthly payment is added to the principal debt of the loan. Approximately 33\% of ARMs initiated from 2004 to 2006 provided incentive rates less than 4\%, which went up after a specified time. The resulting increase could double the monthly payment. The combination of continually loosening restrictions in loan approval, creating initial-period inexpensive monthly payments, and lower initial interest rates caused many applicants to obtain loans that they were not qualified to service and would not be able to maintain after the initial payment periods.

The creation of more readily available loan approvals, reduced monthly payments, and lower interest rates stimulated increased demand for loans. As the volume of loan requests grew significantly, lenders struggled to figure out how to best respond them. This caused a decrease in the rigor of standards for mortgage underwriting policies. Lenders developed automated systems and processes to handle loan approvals that required less review and documentation. By 2007, 40\% of all subprime loan approvals were the result of an automated loan process (Browning, 2007).

The increased demand for subprime loans created a huge opportunity for lenders to originate subprime loans. Lenders responded by streamlining the loan origination process, cutting corners, and creating incentives to attract new borrowers and compete with other lenders. This ultimately resulted in an increase in loan fraud on behalf of both lenders wanting to tap into the huge demand for subprime loans and borrowers wanting to obtain primary homes, vacation homes, and investment properties. The FBI (2005) identified this problem and warned the public of the growing increase in mortgage fraud, which they suggested might be a problem as great as the savings and loan crisis in the 1980s.

\subsection{Mortgage-Backed Securities}

Originally, loans were made between the lender and the borrower and generally stayed that way. This practice changed, however, as securitization came into play. Securitization is the process where risk is mitigated by aggregating loans in a pool and issuing new securities for the pool. Securitization allows banks to distribute the risk of subprime loans by selling them. Creating the ability for banks to sell risky loans eliminates need for institutions to service the loans they sell and hold the loans to maturity. Before the crisis, banks could earn money by originating loans, charging processing fees, and selling loans. This led to more focus on processing loan transactions rather than determining the credit quality of the loans (Purnanandam, 2011).

\subsection{Credit Rating and Government Regulation}

Two other factors contributing to the subprime mortgage crisis were easily available credit and lack of government regulation. MBSs were given investment-grade ratings by credit rating agencies despite their dependence on high-risk subprime ARM loans. The ratings made MBSs attractive to potential investors, creating the housing boom. Many investors mistakenly believed that the diversification provided by MBSs would mitigate the risk. According to the Congressional Committee on Oversight and Government Reform, there are data indicating that stakeholders providing ratings for securities that invested in subprime loans were aware that the rating system was fraught with issues (Towns, 2008). Many allege a conflict of interest for the credit rating agencies, which were paid by firms that sold securities related to subprime mortgages and investment banks.

The government failed to anticipate this crisis and was not able to provide the necessary regulation and deregulation to deal with the changing economy. The economy was deep in the process of shifting to a market-based financial system. Moving to this market-based financial system changed the roles of traditionally regulated firms such as banks and increased the significance of other types of firms such as investment banks, pension funds, and other market-based financial firms, which rapidly changed the requirements for regulation 
and the need for oversight.

\section{Discussion}

The negative consequences experienced during the subprime mortgage crisis can be largely attributed to incentives and the inability of government to adapt to market changes occurring because of those incentives (Jaffee et al., 2009; Purnanandam, 2011). The significant effect that incentives have on employee and executive behavior as well as firm performance are well documented in the literature (Mian \& Sufi, 2009). It would appear that incentives during this time were based more on profit and volume for executives, managers, and brokers/salespersons. This basis seems to have caused the industry to focus on the volume of transactions/sales and shift primary business focus to origination fees rather than long-term lending. When secondary investors became interested in the mortgage market, even more incentive was created for accelerating loans, as there was a perception that risk could be mitigated by selling loans and aggregating them in investment funds. These powerful incentives resulted in predatory lending practices and the creation of loan vehicles without financial basis, where borrowers did not need proof of assets, income, or character to qualify for loans (Arnold, 2007). In general, there was no concern for risk of repayment and no oversight by financial firms or government regulators. Consumer borrowers greatly contributed to this problem as well by pursuing loans they could not afford and looking for a quick win.

The subprime mortgage crisis in the United States was the major catalyst for the global economic downturn of 2008. The crisis had incredible negative impacts on the world financial market and individuals and exhibited many characteristics similar to other financial crises and economic bubbles that burst, which should have been identified. The most common behavior during this period seems to be overexcitement and enthusiasm on the part of bankers, investors, and borrowers. Investors and homeowners should have investigated the reasons for declining interest rates and should not have taken on subprime ARMs with the hope that in a short time rates would go down and they could refinance. Banks and lenders should have understood that taking a huge risk and spreading it across many investors and institutions does not mitigate risk, but merely spreads it to a larger audience, ensuring that many more entities would be affected negatively.

Ultimately, governmental agencies should have identified risks and incentives creating conflict of interests and should not have allowed so much high-risk lending. The subprime mortgage crisis was caused by a lack of proper regulation, investors not researching investments, the desire to make a quick buck, financial institutions offering high-risk loans with no perceived consequences (since they could sell them immediately), and a lack of understanding about how the economy had changed. To avoid these pitfalls in the future several actions need to be considered.

First government regulators need to act judiciously on their responsibilities to provide oversight and guidance for financial transactions, even when players change in the industry. Regulations should elimate predatory lending practices and ensure that loans are qualified properly so that borrowers have a reasonable chance of maintaining and replaying the loan. Financial institution must audit and moderate incentive programs for executives, management, and sales personnel which have powerful effects employee behavior (Kräkel \&Schöttnerb, 2016). Specifically, financial institutions need to clarify the roles of customer and stakeholders and make sure the incentives align with customer interests and there is no conflict of interest with customers and stakeholders (Chatterje, Narayan, and Malek, 2016).

Clearly there is still work to be done in proper alignment of incentive compensation in the financial industry, as evidenced by the recent Wells Fargo incident were employees opened up fake accounts in customers names to meet compensation incentive goals (Poczter, 2016). Quite simply incentives need to be ethically aligned and ensure that they are geared towards benefitting the customer. Lastly, all stakeholders need to analyze opportunities carefully especially during 'bubbles', if a deal looks too good to be true, it likely is.

\section{Acknowledgments}

I would like to thank Allison Humphries for her assistance in manuscript copy editing.

\section{References}

Alexander, B., Apgar, W., Baker, K., Baldwin, P., Belsky, E., \& Zhu, X. (2008). The state of the nation's housing 2008. Retrieved December 7, 2016, from http://www.jchs.harvard.edu/sites/jchs.harvard.edu/files/son2008.pdf: Harvard University.

Arnold, C. (2007). Economists brace for worsening subprime crisis. Retrieved December 17, 2016, from http://www.npr.org/templates/story/story.php?storyId=12561184 
Associated Press. (2007). Will subprime mess ripple through the economy? Retrieved December 17, 2016, from $\mathrm{http}: / /$ www.msnbc.msn.com/id/17584725

Bernanke, B. (2007a). The subprime mortgage market. Retrieved December 7, 2016, from $\mathrm{http}: / / w w w . f e d e r a l r e s e r v e . g o v / n e w s e v e n t s /$ speech/bernanke20070517a.htm

Bernanke, B. (2007b). The recent financial turmoil and its economic and policy consequences. Retrieved December 7, 2016, from http://www.federalreserve.gov/newsevents/speech/bernanke20071015a.htm

Bernanke, B. (2008). Mortgage delinquencies and foreclosures. Retrieved December 7, 2016, from https://www.federalreserve.gov/newsevents/speech/bernanke20080505a.htm

Bernanke, B. (2009). Board of Governors of the Federal Reserve System. Retrieved December 7, 2016, from Four Questions about the Crisis http://www.federalreserve.gov/newsevents/speech/bernanke20090414a.htm

Blinder, A. S. (2010). It's broke, let's fix it: Rethinking financial regulation. International Journal of Central Banking, 6(4), 277-330. Retrieved from http://www.ijcb.org

Browning, L. (2007). The subprime loan machine. Retrieved December 16, 2016, from http://www.nytimes.com/2007/03/23/business/23speed.html?_r=2\&partner=rssnyt\&emc=rss\&oref=slogin

Bush, G. (2008). President Bush's speech to the nation on the economic crisis. Retrieved December 7, 2016, from

http://www.nytimes.com/2008/09/24/business/economy/24text-bush.html?_r=3\&pagewanted=1\&oref=slogi $\mathrm{n}$

Chatterjee, S., Narayanan, V., Malek, W., (2016). How strategy execution maps guided Cisco Systems' sales incentive compensation plan. Strategy \& Leadership 44(6), 25-34. doi:10.1108/SL-08-2016-0071

Christie, L. (2007). Homes: Big drop in speculation. Retrieved from December 7, 2016, http://money.cnn.com/2007/04/30/real_estate/speculators_fleeing_housing_markets/index.htm

Dodd, C. (2007). U.S. Senator Christopher J. Dodd. Retrieved January 7, 2010, Dodd: Create, Sustain, Preserver, and Protect the American Dream of Home Ownership; Stop Abusive Practices in the Housing Market. Retrieve December $\quad 15, \quad 2010$ from http://www.banking.senate.gov/public/index.cfm/2007/2/dodd-create-sustain-preserve-and-protect-the-amer ican-dream-of-home-ownership-stop-abusive-practices-in-the-housing-market

FBI (2005). Mortgage fraud operation "quick flip". Retrieved December 14, 2016, from https://archives.fbi.gov/archives/news/pressrel/press-releases/mortgage-fraud-operation-quick-flip

FDIC (2001). Subprime Lending. Retrieved December 15, 2016, from http://www.fdic.gov/news/news/press/2001/pr0901a.html

Geithner, T. (2008). Federal Reserve Bank of New York. Retrieved January 7, 2010, from Reducing Systematic Risk in a Dynamic Financial System. Retrieved December 21, 2016, from http://www.newyorkfed.org/newsevents/speeches/2008/tfg080609.html

Greenspan, A. (2009, March 26). We need a better cushion against risk. Financial Times. Retrieved December 12, 2016, from http://www.ft.com/cms/s/0/9c158a92-1a3c-11de-9f91-0000779fd2ac.html?nclick_check=1

Hoenig, T. (2008). Maintaining stability in a changing financial system: Some lessons relearned again? Economic Review - Federal Reserve Bank of Kansas City, 93(1), 5-17. Retrieved December 17, 2016 from https://www.kansascityfed.org/publications/research/er

International Money Fund (2009). International Money Fund. Retrieved from Loss Estimates Retrieved December 15, 2016, from http://www.imf.org/external/pubs/ft/weo/2009/01/pdf/exesum.pdf

Jaffee, D., Lynch, A., Richardson, M., \& Van Nieuwerburgh, S. (2009). Mortgage Origination and Securitization in the Financial Crisis. Financial Markets, Institutions and Instruments, 18(2), 141-143. https://doi.org/10.1111/j.1468-0416.2009.00147_4.x

Jesson, J., Matheson, L., \& Lacey, F. (2011). Doing Your Literature Review. Los Angeles, CA: Sage Publications Ltd.

Kräkel, M., Schöttnerb, A. (2016). Optimal sales force compensastion. Journal of Economic Behavior \& Organziation, 126, 179-195. https://doi.org/10.1016/j.jebo.2016.03.015

Mian, A., \& Sufi, A. (2009). The Consequences of Mortgage Credit Expansion: Evidence from the U.S. 
Mortgage Default Crisis. The Quarterly Journal of Economics, 124(4), 1449-1496. https://doi.org/10.1162/qjec.2009.124.4.1449

Mortgage Bankers Association (2007). Delinquencies and foreclosures increase in latest MBA national $\begin{array}{lllll}\text { delinquency } & \text { survey. } & \text { Retrieved } & \text { November } & 12,\end{array}$ http://www.mbaa.org/NewsandMedia/Pressenter/58758.htm

Mortgage Bankers Association (2009, November 19). Delinquencies continue to climb in latest MBA national

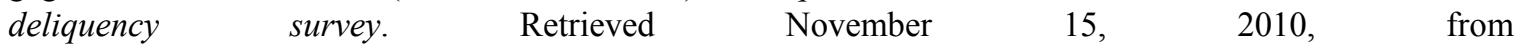
http://www.mbaa.org/NewsandMedia/PressCenter/71112.htm

Poczter, S. (2016). Banking ethics problems run much deeper than Wells Fargo, retrieved on January 1, 2017, from

http://www.americanbanker.com/bankthink/bankings-ethics-problems-run-much-deeper-than-wells-fargo-1 092407-1.html

Purnanandam, A. (2011). Originate-to-distibute model and the sub-prime mortgage crisis. Review of Financial Studies, 24(6). https://doi.org/10.1093/rfs/hhq106

Reuters (2007). Spending boosted by home equity loans: Greenspan. Retrieved December 13, 2016, from http:/www.reuters.com/article/idUSN2330071920070423

Steverman, B., \& Bogoslaw, D. (2008). The financial crisis blame game. Retrieved November 12, 2010, from http://www.businessweek.com/investor/content/oct2008/pi20081017_950382.htm?chan=top+news_top+ne ws+index+-+temp_top+story

Towns, E. (2008). Committee holds hearing on the credit rating agencies and the financial crisis. Retrieved January $10, \quad 2010, \quad$ from http://oversight.house.gov/index.php?option=com_content\&task=view\&id=3437\&Itemid=2

Wiedemer, J. (2000). Real Estate Finance (8th ed.). Florence, KY: South-Western Educational Publishing.

\section{Copyrights}

Copyright for this article is retained by the author(s), with first publication rights granted to the journal.

This is an open-access article distributed under the terms and conditions of the Creative Commons Attribution license (http://creativecommons.org/licenses/by/4.0/). 